\title{
The morphology of the preimaginal stages of Squamapion elongatum (Germar, I 8I 7) (Coleoptera, Curculionoidea, Apionidae) and notes on its biology
}

\author{
Jacek Łętowski', Krzysztof Pawlęga', Radosław Ścibior', Karol Rojek² \\ I Department of Zoology, Animal Ecology and Wildlife Management, University of Life Sciences in Lublin, \\ Lublin, Poland 2 Department of Applied Pharmacy, Medical University of Lublin, Lublin, Poland \\ Corresponding author: Jacek Eętowski (jacek.letowski@up.lublin.pl)
}

Academic editor: M. Alonso-Zarazaga | Received 15 December 2014 | Accepted 14August 2015 | Published 1 September 2015

http://zoobank.org/13635001-75BA-43EF-8A85-F7647D259C9C

Citation: Łętowski J, Pawlęga K, Ścibior R, Rojek K (2015) The morphology of the preimaginal stages of Squamapion elongatum (Germar, 1817) (Coleoptera, Curculionoidea, Apionidae) and notes on its biology. ZooKeys 519: 101-115. doi: $10.3897 /$ zookeys.519.9134

\begin{abstract}
Data on the morphology of the egg, mature larva $\left(\mathrm{L}_{3}\right)$ and pupa of Squamapion elongatum (Germar, 1817) are presented. The development cycle of this species lasts 51-54 days: a 12-day egg period, a 30-day larval period, and a 12-day pupal period, on average. The larvae are attacked by parasitic hymenopterans of the superfamily Chalcidoidea.
\end{abstract}

\section{Keywords}

Weevil, Apionidae, Squamapion, egg, mature larva, pupa, life cycle, Salvia, Lamiaceae

\section{Introduction}

The genus Squamapion Bokor, 1923 is distributed in the Palaearctic and Afrotropical regions and includes 33 species (Alonso-Zarazaga 2011). In Poland it is represented by 9 species: Squamapion atomarium (Kirby, 1808), S. cineraceum (Wencker, 1864), S. elongatum (Germar, 1817), S. flavimanum (Gyllenhal, 1833), S. serpyllicola (Wencker, 1864), S. mroczkowskii (Wanat, 1997), S. oblivium (Schilsky, 1902), S. samarense (Faust, 1891) and S. vicinum (Kirby, 1808) (Petryszak 2004; Mokrzycki and 
Wanat 2005). These are mono- or oligophagous herbivores feeding on species from the family Lamiaceae, mainly of the genera Salvia, Thymus, Thymbra, Mentha, Origanum, Prunella and Saccocalyx. Their larvae burrow tunnels inside roots or stems, occasionally causing galls (Alonso-Zarazaga 1990). These insects are quite similar in terms of external morphology, which causes many problems in identification. As yet no attempts have been made to divide the taxon into subgenera or species groups (Wanat 1997).

Squamapion elongatum is a species inhabiting the southern and central part of Europe, as well as East Asia and Algeria. It inhabits lowland and submontane areas. In Poland it is recorded in the Masurian Lake District, the Wielkopolsko-Kujawska Lowland, Upper and Lower Silesia, the Krakowsko-Wieluńska Upland, the Małopolska Upland, the Świetokrzyskie Mountains, the Lublin Upland, Roztocze and Eastern Beskid (Burakowski et al. 1992). This species is characteristic of xerothermic grasslands, where it feeds on plants of the genus Salvia - S. pratensis and S. nemorosa (Cmoluch 1962). Its life cycle has not yet been described.

\section{Material and methods}

Squamapion elongatum eggs, larvae, pupae and adults were collected from two patches of xerothermic grasslands in Gródek (5046'58.18"N, 2356'47.04"E) near Hrubieszów and in Łęczna (51 $\left.18^{\prime} 9.7^{\prime \prime} \mathrm{N}, 22^{\circ} 51^{\prime} 47.8^{\prime \prime E}\right)$ (SE Poland). The material was collected during one growing season from July to September 2011 at 3-7 day intervals between 10 a.m. and 2 p.m. Adults were collected using an entomological net in an association of Thalictro-Salvietum pratensis. To obtain the other development stages for breeding, whole plants of the genus Salvia were collected. In total 67 specimens of meadow sage were collected. A delicate cut was made along the stem and root of the plants and then they were dissected with needles to find the eggs, larvae, pupae and even adults located inside. Some of the larvae were used to begin breeding and others for microscopic slides, to be used in making drawings showing the morphology of the developmental stages. To prepare the drawings we used an OLYMPUS BX61 microscope at magnifications from $200 \times$ to $400 \times$ and a TESCAN VEGA3LMU scanning microscope at magnifications from $500 \times$ to $4,500 \times$. The figures were made based on the biological preparations using Corel Draw 12 software. Metric sizes are the average value of 10 measurements (Table 1).

Larval specimens in successive developmental stages were transferred in vitro to Petri dishes after the larval stadium was determined on the basis of morphological characteristics and the number of exuvia of head capsules. Breeding of larvae was carried out to the $\mathrm{L}_{3}$ stage. Breeding of preimaginal stages was carried out according to Scherf (1964) and Łętowski (1991). Petri dishes were transferred to a breeding chamber with the following conditions: temperature during the day $30{ }^{\circ} \mathrm{C}$, temperature at night $20{ }^{\circ} \mathrm{C}$, humidity during the day $60 \%$, humidity at night $80 \%$. Adults were kept in glass containers covered with a fine mesh. As in the case of the larvae, filter paper saturated with distilled water was placed at the bottom to maintain humidity and as 
Table I. The measurement values of length and width of larvae $\left(\mathrm{L}_{3}\right)$ and pupae bodies.

\begin{tabular}{c|c|c|c|c}
\hline \multirow{2}{*}{ No } & \multicolumn{2}{|c|}{ Larva $\left(\mathbf{L}_{3}\right)$} & \multicolumn{2}{c}{ Pupa } \\
\cline { 2 - 5 } & length & width & length & width \\
\hline 1 & 2.80 & 1.28 & 2.69 & 0.93 \\
\hline 2 & 2.76 & 1.24 & 2.68 & 0.95 \\
\hline 3 & 2.81 & 1.22 & 2.67 & 0.96 \\
\hline 4 & 2.75 & 1.23 & 2.66 & 0.92 \\
\hline 5 & 2.78 & 1.26 & 2.65 & 0.93 \\
\hline 6 & 2.77 & 1.25 & 2.69 & 0.98 \\
\hline 7 & 2.79 & 1.24 & 2.65 & 0.95 \\
\hline 8 & 2.81 & 1.22 & 2.67 & 0.94 \\
\hline 9 & 2.75 & 1.26 & 2.69 & 0.93 \\
\hline 10 & 2.78 & 1.24 & 2.67 & 0.95 \\
\hline average & 2.78 & 1.24 & 2.67 & 0.94 \\
\hline
\end{tabular}

a possible reservoir of drinking water for the beetles. They were fed with fragments of fresh sage shoots, which were replaced on average every three days. The used stems were examined to search for eggs. Microscope slides with the developmental stages and their morphological structures were prepared according to Łętowski (1991) and Gosik et al. (2010). The terminology of Scherf (1964), May (1993, 1994), Marvaldi (2003) and Wang et al. (2013) was used in the morphological description of the larva and pupa. The morphology of the egg, $\mathrm{L}_{3}$ and pupa and the developmental cycle from egg to adult were described.

Setae of thorax and abdomen of larva $\left(\mathrm{L}_{3}\right)$ and pupa are described for one side only.

\section{Description}

\section{Egg (Figure 11)}

Length ca. $1.13 \mathrm{~mm}$, width ca. $0.57 \mathrm{~mm}$, oval, smooth, shiny, whitish-yellow.

Mature larva $\left(\mathbf{L}_{3}\right)$ (Figures 1, 12)

Length ca. $2.78 \mathrm{~mm}$, width ca. $1.24 \mathrm{~mm}$. Body massive and strongly curved, whitish-yellow, with short setae.

Head (Figures 2, 9, 10): Yellow-brown, oval, with clear frontal suture completely extended to mandibular joint. Epicranium: length ca. $0.72 \mathrm{~mm}$, width ca. $0.56 \mathrm{~mm}$. Endocarina (enc) long, extended to $2 / 3$ the length of the frons. One pair of ocelli (oc). Antennae (at) with conical sensorium and 2 small spinose sensilla (Fig. 10). Clypeus with 1 pair of short setae $(c l s 1)$. Frons with 5 pairs of setae $\left(f_{s}\right)-f_{s} 2$ and $f s 5$ longer, $f_{s} 1$, $f s 3$ and $f_{s} 4$ much shorter, at the apex of the endocarina, $f_{s 2}-4$ near the epistoma, $f_{s} 5$ close to the antennae (Fig. 2). Epicranium with 2 pairs of lateral setae (les) - les 1 short, les 2 long, more than 3 times longer than les1.; 5 pairs of dorsal setae (des) - des 1 very 


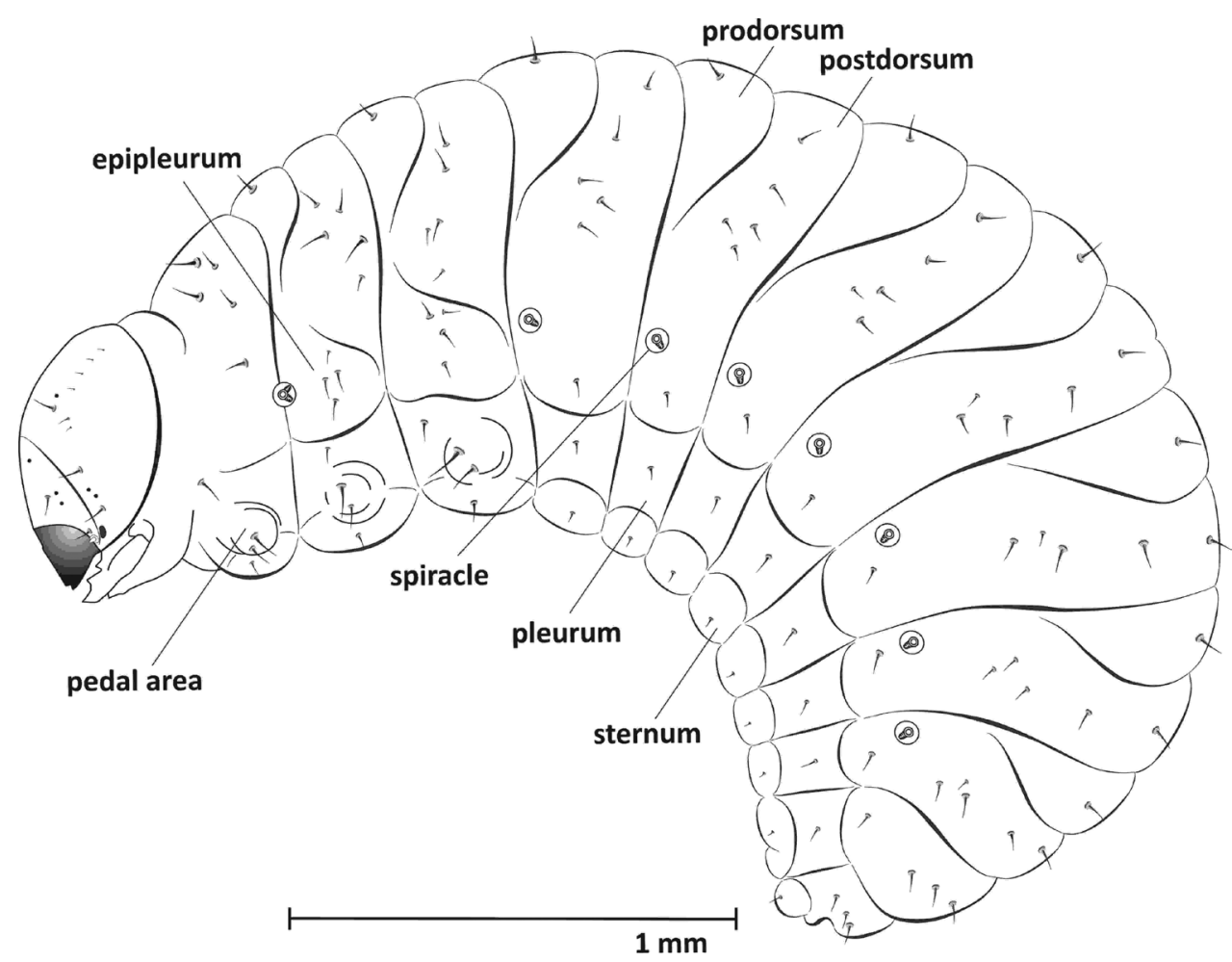

Figure I. Mature larva $\left(\mathrm{L}_{3}\right)$, lateral view.

long, des 2 and des 5 a bit shorter and des 3 and des 4 much shorter; 4 pairs of minute posterior setae (pes) (in line with des2); 1 sensillum between epicranial suture and pes and another sensillum laterally to des 1 and close to des 2 .

Mouthparts (Figures 3-5, 9): Dorsal side of labrum with 3 pairs of setae (Irms13) - lrms 1 and 2 long, lrms 3 nearly half the length of lrms2. Epipharynx with 7 pairs of setae ( 3 ams, 3 als, 1 mes) and rather short labral rods (lmr) (Fig. 3a, b). Mandibles massive, dark brown, with 2 mandibular setae $(m d s 1,2)$ and 2 sensilla (Fig. 4). Maxillae: palpifer with 2 long setae $(p f s 1,2)-p f s 2$ longer than $p f s 1,1$ longer stipital seta $(s t p s I)$ and 2 very short sensilla. Maxillary palpus with 2 segments. Basal segment with digitiform sensorium and 3 very short setae, distal segment cylindrical with 1 short sensilla and 10 conical papillae. Lacinia with 8 robust setae arranged like a comb (dms) (Fig. 5, 9). Labium: premental sclerite ( $p m s c)$ Y-shaped. Mentum-submentum complex with 2 pairs of postmental setae (pms1,3) and 3 pairs of prelabial setae (prms1-3) - prms 1 short, prms 2 and 3 very short. Additionally, submentum with 3 pairs of sensilla. Labial palpi $(l b p)$ 1-segmented, raised, with numerous papillae (Fig. 5).

Thorax. Pronotal shield unsclerotized, meso- and metanotum each with 2 folds: pro- and postdorsum. Thoracic spiracle intersegmental, in membrane between pro- 


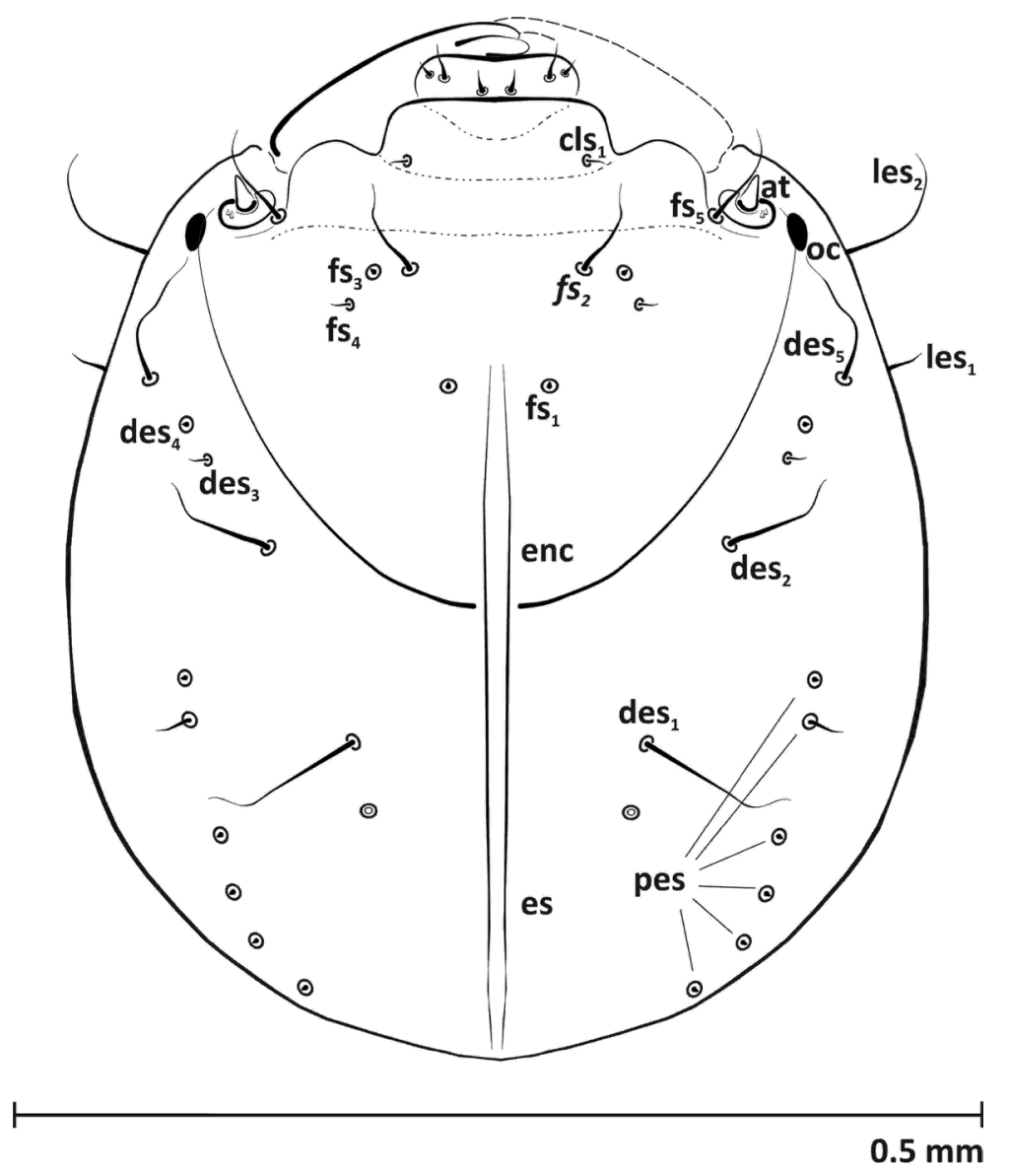

Figure 2. Epicranium $\left(\mathrm{L}_{3}\right)$, dorsal view: les lateral epicranial setae $\mathbf{f s}$ frontal $\mathrm{s}$. des dorsal s. pes posterior epicranial s. cls clypeus s. at antenna oc ocellus enc endocarina, es endocarina suture.

and mesothorax, bicameral. Prothorax with 7 setae: pronotum with 5, epipleurum indistinct, with 1 seta, sternum with 1 seta. Meso- and metathorax with 12 setae: prodorsum with 1 seta, postdorsum with 5 setae, epipleurum (clearly visible) with 4 clear setae, pleurum and sternum with 1 seta. Pedal area with two long setae for all segments (Fig. 1).

Abdomen. Tergites I-VII with 2 folds, prodorsum with 1 seta on the ridge, postdorsum with 6 setae -5 dorsally located and 1 seta surrounded by a circle of sparse tubercles. Tergites VIII-IX without folds (single), VIII with 4 setae and XI with 3 setae, reduced. Segments I-VII with unicameral spiracles, others without spiracles. Pleura and sterna I-VIII with 1 short seta, sterna IX with 1 short seta (Fig. 1).

Pupa (Figures 6-8, 13)

Body length: ca. $2.67 \mathrm{~mm}$, width ca. $0.94 \mathrm{~mm}$. Colour whitish-grey. 

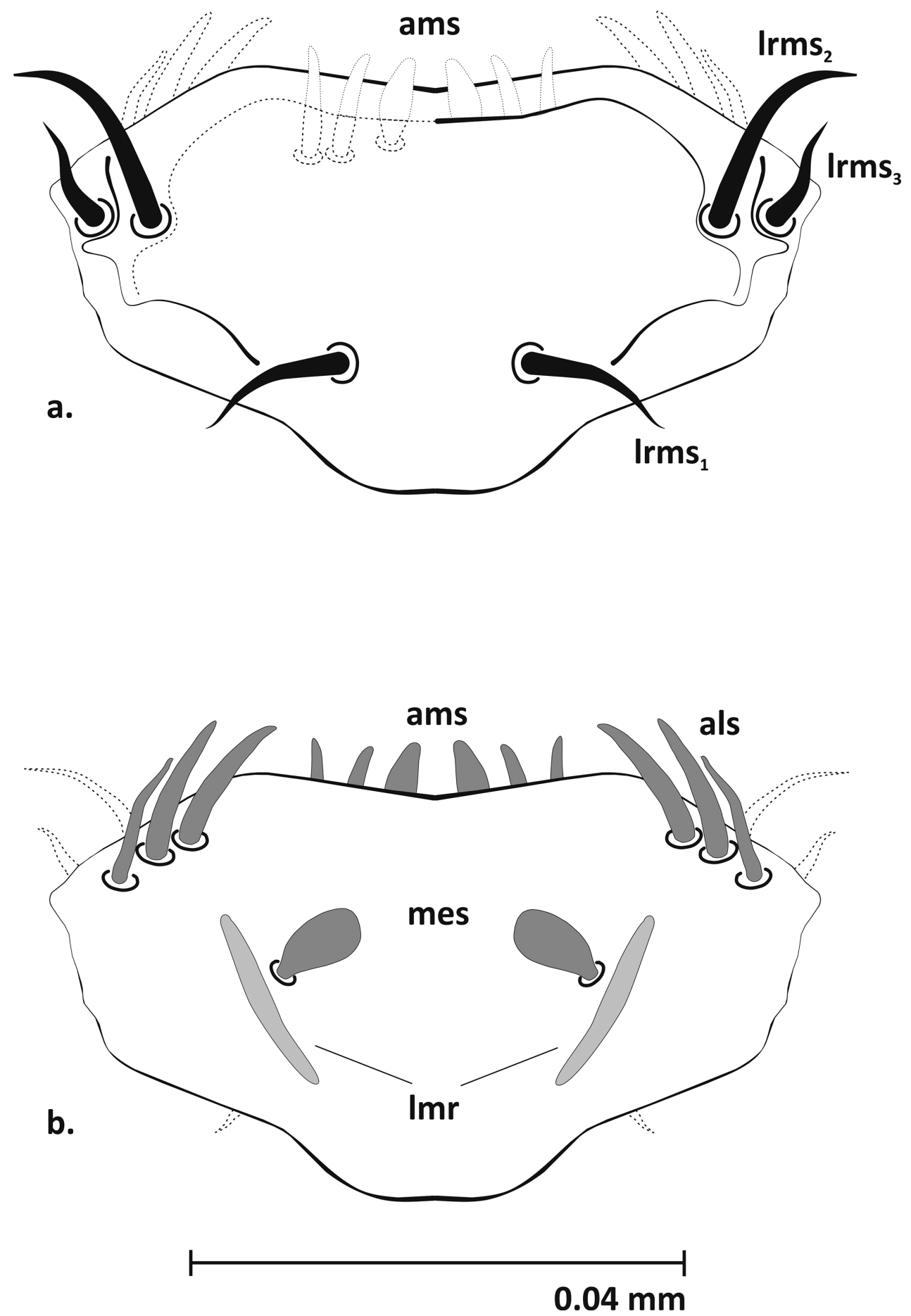

Figure 3. Labrum and epipharynx $\left(\mathrm{L}_{3}\right)$ (a dorsal b ventral view): a Irms labral setae b mes median $s$. ams anteromedial s. als anterolateral s. Imr labral rods. 


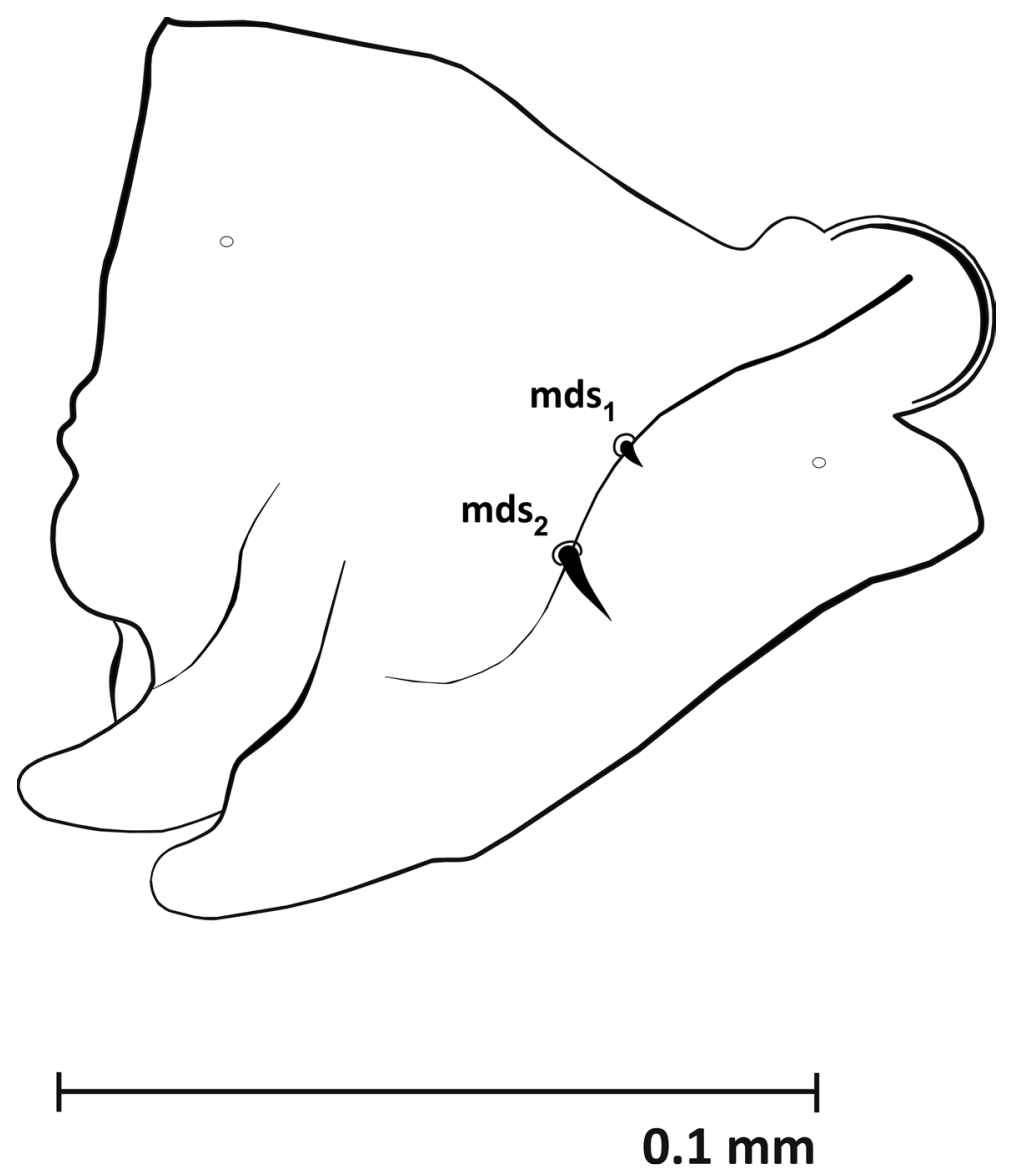

Figure 4. Mandible $\left(\mathrm{L}_{3}\right)$, left: $\boldsymbol{m} \boldsymbol{d} \boldsymbol{s}$ dorsal malae setae.

Head (ventral view). Rostrum reaching ventrite V, with 1 distinct seta ( $r s)$ at midlength, in front of the antennal insertion. Antennae relatively long, club with conical papillae. Antennae sub-parallel to protibia. Frons with 1 pair of setae (vs), about as long as rostral setae, situated at the level of the hind margin of the eyes (Figs 6,7). Pronotum length greater than width, with 5 pairs of setae (as 1, as2, sls, pls1, pls2) (Figs 6-8). Setae asland as 2 long and located at the apical margin. Setae sls a bit shorter, located at the external margin in the middle of the edge. Setae pls1and pls 2 as long as $s l$, and located close to the back margin. Mesonotum short and metanotum two times longer than mesonotum. Mesonotum with clearly visible scutellar shield, metanotum with 3 pairs of short setae, medially located. All femora with 1 long, thin seta (fes 1-3) located apically (Figs 6-8). Abdomen. Abdominal tergites I-III with 7 pairs of setae arranged in two rows -2 closer to the upper edge of the segment, nearly at the external margin, 5 closer to the base. Tergites IV-VI with 5 pairs of setae arranged in two rows -1 closer to the upper edge of the segment, nearly at the external margin, 4 closer to 


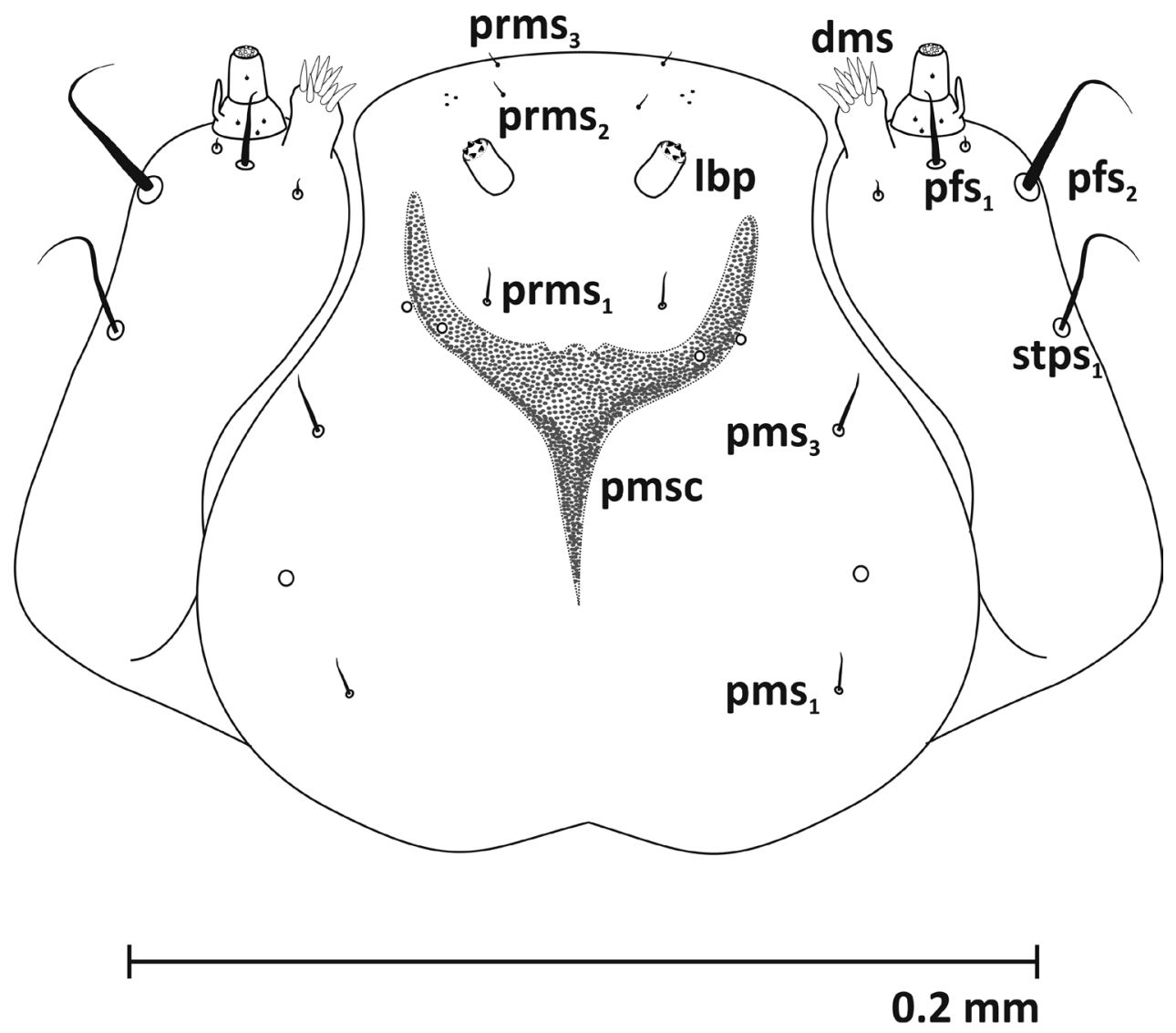

Figure 5. Maxillae and labium $\left(\mathrm{L}_{3}\right)$ : dms dorsal maxillary setae pfs palpiferal s. stps stipal s. prms prelabium s. pms postlabium s. pmsc premental sclerite lbp labial palpus.

the base. Tergite VII with 3 pairs of setae arranged in one row, VIII with one pair. Segment IX without setae. Urogomphi (pseudocerci) ( $p c$ ) on abdominal segment IX, laterally parted, crescent-shaped, narrow. Segment X reduced (Figs 6-8, 14). Spiracles on abdominal segments I-VI functional, well visible, positioned longitudinally on pleura (Fig. 6). Gonotheca visibly divided in female, single in male.

\section{Biological information}

According to the available literature, the period of occurrence of adults of Squamapion elongatum is April (Cmoluch 1962). During sampling they were found only on meadow sage, although woodland sage was also examined. This confirms Dieckmann's (1977) observations in Central European conditions that meadow sage is the food and breeding plant of this species. It was observed that fertilized females bit out small holes in the 


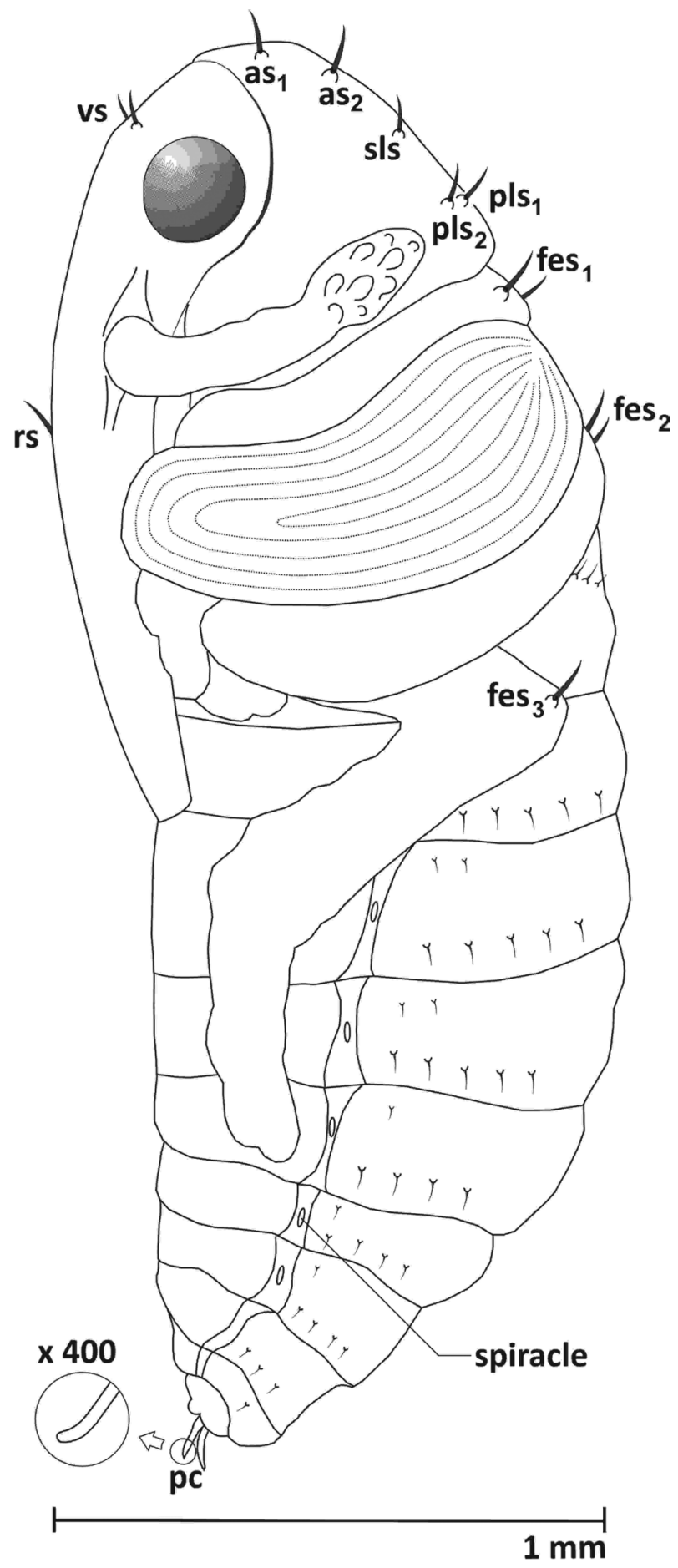

Figure 6. Pupa, lateral view: as apical s., s/s sublateral s., pls posterolateral s. vs vertical s. rs rostral s. fes femoral s. pc urogomphi. 


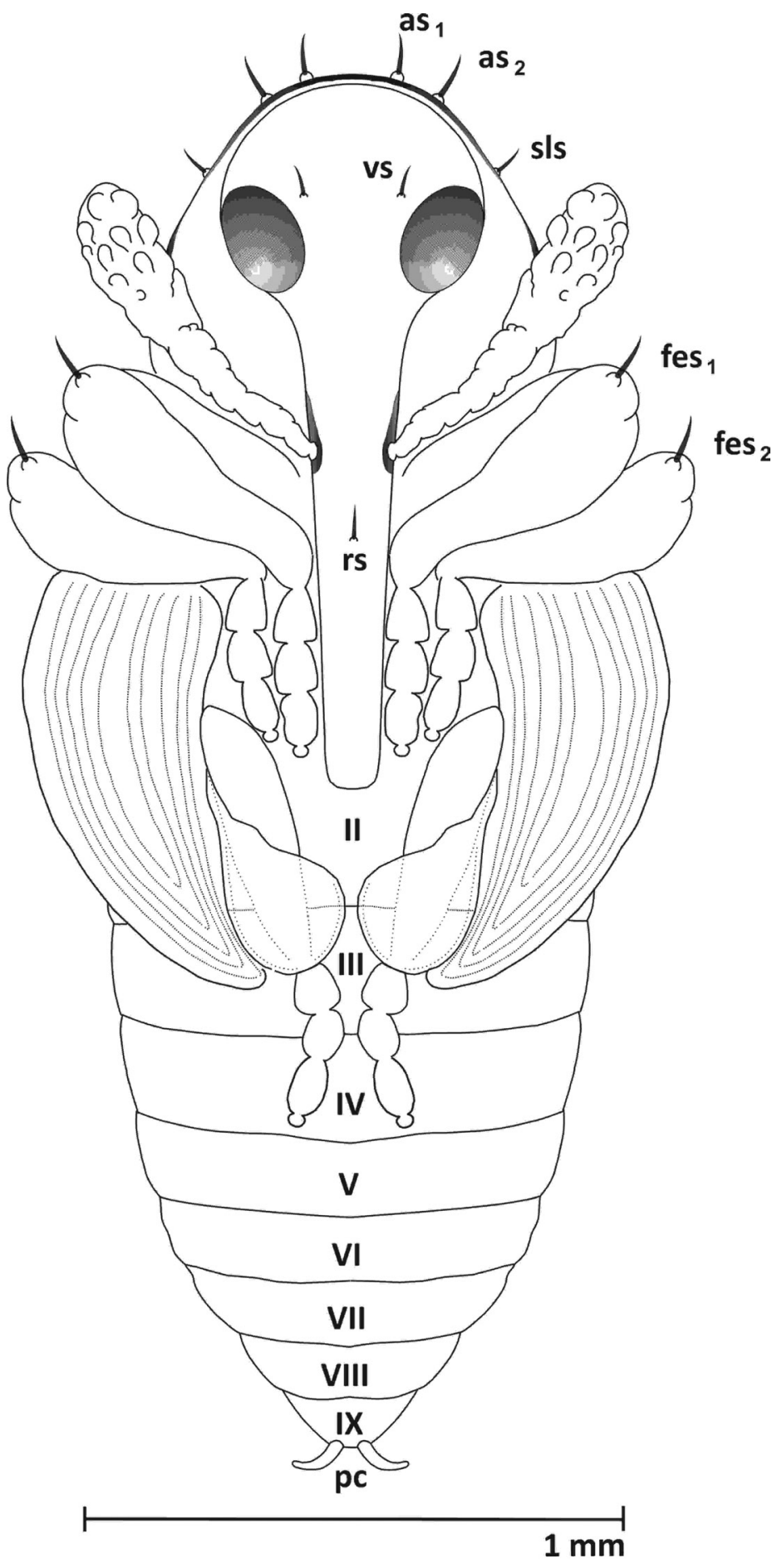

Figure 7. Pupa, ventral view: as apical s. sls sublateral s. vs vertical setae rs rostral s. fes femoral s. pc urogomphi. 


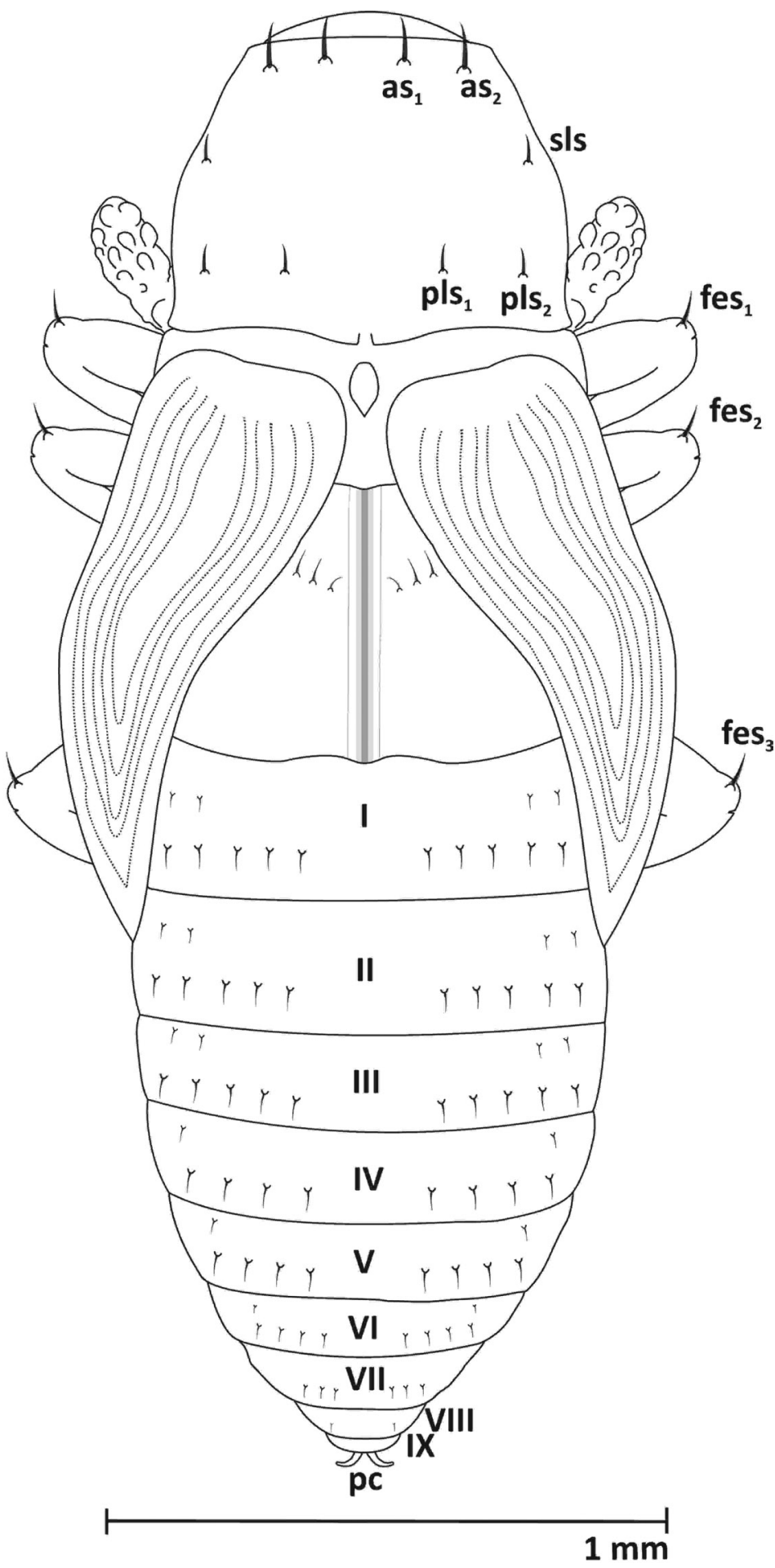

Figure 8. Pupa, dorsal view: as apical s. sls sublateral s. pls posterolateral s. fes femoral s. pc urogomphi. 


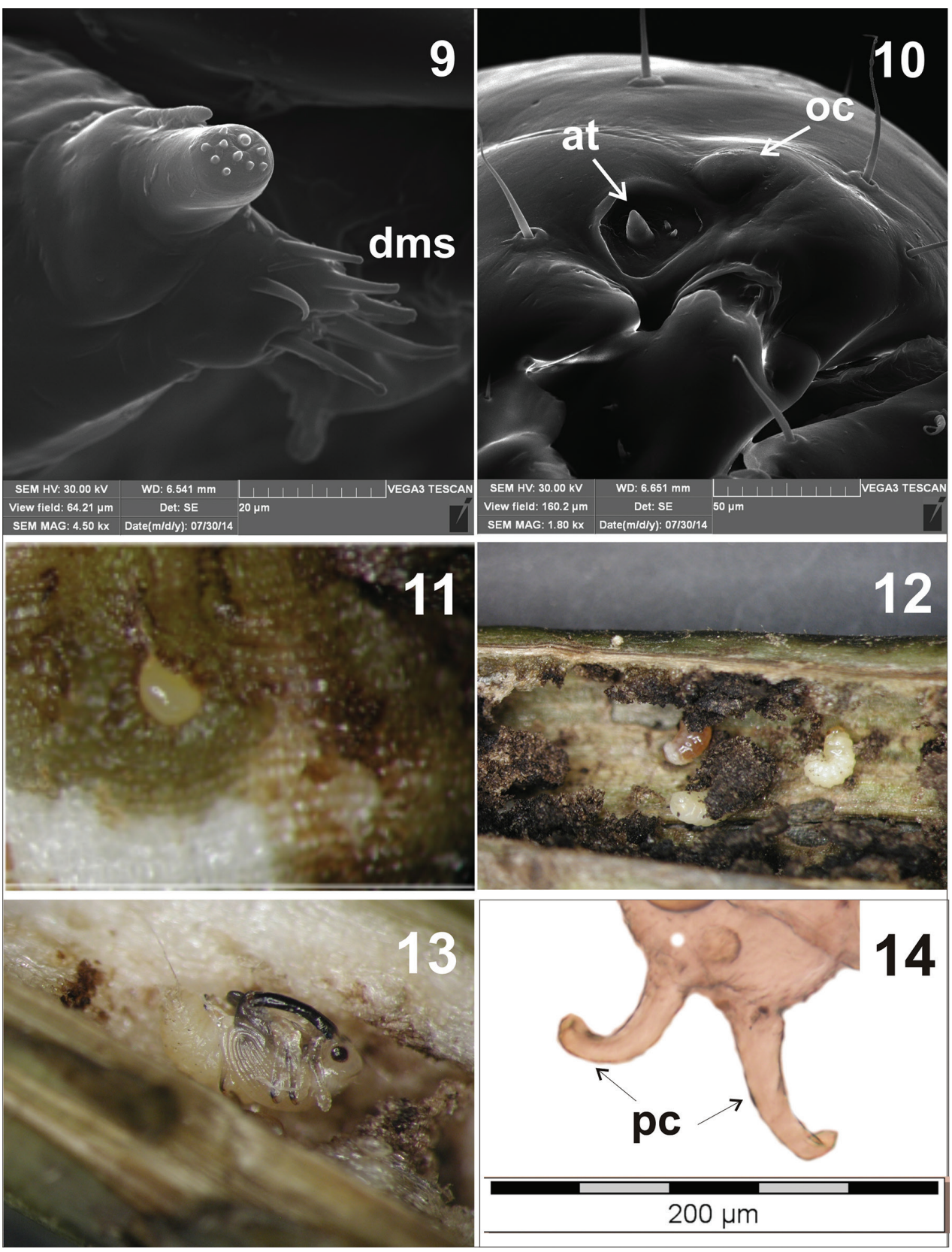

Figures 9-I 4. 9 Maxillary palpus (dms - dorsal robust setae) I 0 ocellus (oc) and antenna (at) I I egg I $2 \mathrm{~L}_{3}$ during construction of the pupal chamber $\mathbf{3}$ pupa $\mathbf{1 4}$ urogomphi (pc).

nodes and internodes of the sage stems, in which they laid eggs. Often there were two or more larvae in one place, suggesting that females can lay several eggs in one hole. The oldest larvae were found on the root of the host plant, while the younger larvae were 
observed higher up, to about $2 / 3$ of the plant height. After an average of 12 days (from 10 to 14 days), the larvae of the first instar $\left(\mathrm{L}_{1}\right)$ hatched and enlarged the egg chamber, making contact with the pith inside the stem. Here the larvae fed intensively, creating tunnels. After about seven days the larvae finished moulting, leading to $\mathrm{L}_{2}$. $\mathrm{L}_{2}$ fed on average for 10 days, extending the tunnels begun by $\mathrm{L}_{1}$. The life span of $\mathrm{L}_{3}$ ranged from 10 to 13 days (data based on laboratory cultures and field observations). The greatest weight gain in the larvae occurred during this period, as well as preparation for pupation. The larvae dig a tunnel 6-12 $\mathrm{mm}$ in length and use loose fibres to build a pupal chamber (Fig. 12). Initially the pupa was white; later it assumed a creamy shade, and as pigmentation progressed it turned grey. The eyes and rostrum took on the colour first, then the femorotibial articulations and tarsi, followed by the secondary pterothecae, and gradually the rest of the body. The pupal period lasted 12 days on average, and the development cycle of one generation from egg to imago lasted on average 51-54 days.

Larvae of this weevil were attacked by parasitic hymenopterans of the Chalcidoidea. Both internal (Entedon Dalman, 1820 sp.) and external (Trichomalus Thomson, 1878 sp.) parasites from that superfamily were observed.

\section{Discussion}

This is the first description of the immature stages of a species of the genus Squamapion. The features described were compared with those described by Scherf (1964) for the genus Apion Herbst, 1797 sensu lato, by Marvaldi (2003) for Apioninae, by Łętowski (1991) for Stenopterapion Bokor, 1923, Omphalapion Schilsky, 1906 and Hemitrichapion Voss, 1959, by Gosik et al. (2010) for Diplapion Reitter, 1916, by Wang et al. (2013) for Pseudaspidapion Wanat, 1990 and by Alonso-Zarazaga and Wanat (2014) for Apioninae Schoenherr, 1823.

The morphology of the egg does not differ substantially from the typical characteristics of the eggs of apionid beetles. The localization of eggs on the plant and the duration of this stage are also similar to those of other apionid beetles with the same lifestyle.

In general the body of larval $S$. elongatum does not deviate from representatives of the subfamily Apioninae described by Alonso-Zarazaga and Wanat (2014). It is very similar to that of larvae of species living inside common sainfoin described by Łętowski (1991) or Diplapion confluens (Kirby, 1808) living in the roots of Anthemis tinctoria L. (Gosik et al. 2010). The larvae of $S$. elongatum have a typical number of spiracles for Apionidae, as described in Emden (1938), Scherf (1964) and Łętowski (1991), the absence of spiracles on abdominal segment VIII being an important apomorphic character defining the group (as Apioninae in Marvaldi 2003). Larvae of different stages differ from one another in some characteristics, mainly changes in the distribution pattern of the setae. However, no change in the colour of the larvae was observed during growth, unless caused by internal parasitic infection. The differences in the chaetotaxy of the larval body are shown using $\mathrm{L}_{3}$ of Squamapion elongatum, Diplapion confluens and Pseudaspidapion botanicum as examples (Table 2). 
Table 2. Character comparison between Squamapion elongatum, Diplapion confluens and Pseudaspidapion botanicum.

\begin{tabular}{|c|c|c|c|c|}
\hline \multicolumn{2}{|c|}{ Species } & Squamapion elongatum & Diplapion confluens & $\begin{array}{l}\text { Pseudaspidapion } \\
\text { botanicum }\end{array}$ \\
\hline \multicolumn{2}{|c|}{$\begin{array}{c}\text { arrangement of setae pes on } \\
\text { epicranium }\end{array}$} & $\begin{array}{l}4 \text { pairs of minute posterior } \\
\text { setae }(p e s 1-4) \text { separated } \\
\text { from one pair of longer setae } \\
(\text { pes } 5) \text { and } 1 \text { pair of sensilla }\end{array}$ & $\begin{array}{l}2 \text { pairs (pes } 1, \text { pes } 2) \\
\text { short and blunt }\end{array}$ & $\begin{array}{l}6 \text { pairs of setae, pes } 1 \\
\text { shortest, pes } 2-6 \\
\text { successively longer }\end{array}$ \\
\hline \multirow{2}{*}{$\begin{array}{c}\text { number of setae } \\
\text { on maxillary } \\
\text { palpus }\end{array}$} & basal segment & 3 very short setae & $\begin{array}{c}1 \text { long and } 1 \text { micro } \\
\text { seta }\end{array}$ & $\begin{array}{c}1 \text { short inner seta and } 1 \\
\text { sensillum }\end{array}$ \\
\hline & distal segment & 1 short sensilla & none & 1 crenulate seta \\
\hline \multicolumn{2}{|c|}{ length of labral rods ( $(m r)$} & rather short & long & long \\
\hline \multicolumn{2}{|c|}{ occurrence $p m s 2$} & present & present & absent \\
\hline \multicolumn{2}{|c|}{$\begin{array}{c}\text { number of setae on the } \\
\text { mandibles }\end{array}$} & 2 & 1 & 1 \\
\hline \multirow{2}{*}{$\begin{array}{l}\text { number of } \\
\text { conical papillae }\end{array}$} & $d m s$ & 8 & 5 & 5 \\
\hline & vms & 0 & 2 & 4 \\
\hline \multicolumn{2}{|c|}{$\begin{array}{c}\text { number of setae }(p n s) \text { on } \\
\text { pronotum }\left(\mathrm{L}_{3}\right)\end{array}$} & 5 & 4 & 6 \\
\hline
\end{tabular}

The characteristics of the pupae of this weevil species do not differ from other representatives of Apionidae, except for the presence of a mesofemoral seta, also found in Diplapion but not in Pseudaspidapion, and the lack of a pair of setae on the 8th abdominal tergite, in contrast to one pair of setae in Pseudaspidapion and two in Diplapion. Relatively long urogomphi flared to the sides were present, as in Pseudaspidapion and Diplapion (Gosik et al. 2010; Wang et al. 2013).

The laboratory work confirmed that the food and breeding plant for this species is meadow sage (Salvia pratensis). The preimaginal development of S. elongatum occurs in the nodes and internodes of the stems, as well as in the basal part of the root.

\section{References}

Alonso-Zarazaga MA (1990) Revision of the supraspecific taxa in the Palaearctic Apionidae Schoenherr, 1823 (Coleoptera, Curculionoidea). Subfamily Apioninae Schoenherr, 1823: Introduction, Keys and Descriptions. Graellsia 46: 19-156.

Alonso-Zarazaga MA (2011) Apionidae. In: Löbl I, Smetana A (Eds) Catalogue of Palaearctic Coleoptera, Vol. 7. Stenstrup, Apollo Books, 373 pp.

Alonso-Zarazaga MA, Wanat M (2014) Apioninae Schoenherr, 1823. In: Leschen RAB, Beutel RG (Eds) Handbook of Zoology/ Handbuch der Zoologie, Band 4: Arthropoda, 2. Hälfte: Insecta, Coleoptera, Beetles, Volume 3: Morphology and Systematics (Phytophaga). De Gruyter, Berlin, Boston, 395-415. 
Burakowski B, Mroczkowski M, Stefańska J (1992) Katalog Fauny Polski. Cz. XXIII, T. 18. Chrząszcze (Coleoptera). Ryjkowcowate prócz ryjkowców - Curculionoidea prócz Curculionidae. Cz. 3. Wyd. Muz. i Inst. Zool. PAN, Warszawa, 324 pp.

Cmoluch Z (1962) Badania nad fauną ryjkowców (Coleoptera, Curculionidae) roślinnych zespołów kserotermicznych południowo-wschodniej części Wyżyny Lubelskiej. Annales Universitatis Mariae Curie-Skłodowska, sectio C, 17(1): 1-75.

Dieckmann L (1977) Beiträge zur Insektenfauna der DDR: Coleoptera - Curculionidae (Apioninae). Beiträge zur Entomologie 27: 7-143.

Emden Fv (1938) On the taxonomy of Rhynchophora larvae (Coleoptera). Transactions of the Royal Entomological Society of London 87: 1-37. doi: 10.1111/j.1365-2311.1938. tb01800.x

Gosik R, Łętowski J, Kozak E (2010) Morphology of the mature larva and pupa of Diplapion confluens (Kirby, 1808) (Coleoptera: Apionidae). Polish Journal of Entomology 79: 211-221.

Łętowski J (1991) Morfologia i biologia trzech gatunków z rodzaju Apion Herbst (Apionidae, Coleoptera) uszkadzających sparcetę siewną (Onobrychis viciaefolia Scop.). Wydawnictwo Uniwesytetu Marii Curie-Skłodowkiej, 95 pp.

Marvaldi AE (2003) Key to larvae of the South American subfamilies of weevils (Coleoptera: Curculionoidea). Revista Chilena de Historia Natural 76: 603-612. doi: 10.4067/S0716078X2003000400005

May BM (1993) Larvae of Curculionoidea (Insecta: Coleoptera): a systematic overview. Fauna of New Zealand 28: 1-221.

May BM (1994) An introduction to the immature stages of Australian Curculionoidea, subfamily Bagoinae. In: Zimmerman EC (Ed.) Australian Weevils 2: 533-535.

Mokrzycki T, Wanat M (2005) A new checklist of the weevils of Poland (Coleoptera: Curculionoidea). Genus 16(1): 69-117.

Petryszak B (2004) Curculionoidea. In: Bogdanowicz W, Chudzicka E, Pilipiuk I, Skibińska E (Eds) Fauna of Poland. Characteristics and checklist of species. Museum i Instytut Zoologii PAN, Warszawa, Vol. I, 509 pp.

Scherf H (1964) Die Entwicklungsstadien der mitteleuropäischen Curculioniden (Morphologie, Bionomie, Ökologie). Verlag Waldemar Kramer, Frankfurt am Main, 335 pp.

Wanat M (1997) New and little known Squamapion species (Coleoptera: Apionidae) from western Palaearctic. Annales Zoologici 47(1/2): 285-295.

Wang Z, Alonso-Zarazaga MA, Zhou D, Zhang R (2013) A description of preimaginal stages of Pseudaspidapion botanicum Alonso-Zarazaga et Wang, 2011 (Apionidae, Curculionoidea). ZooKeys 260: 49-59. doi: 10.3897/zookeys.260.4450 